Article

\title{
Intercultural Struggle and the Targeting of Noncombatants: The Case of the Islamic State
}

\author{
Ross Moret ${ }^{1, *}$ and Simone Burgin ${ }^{2}$ \\ 1 Florida State University, Honors Program, 127 Honors Way, Tallahassee, FL 32306, USA \\ 2 Florida State University, Tallahassee, FL 32306, USA; smb17c@my.fsu.edu \\ * Correspondence: rmoret@fsu.edu
}

Received: 28 June 2018; Accepted: 23 July 2018; Published: 27 July 2018

\begin{abstract}
The prohibition against targeting noncombatants is a long-held commitment in both Muslim and Western military ethics. Nevertheless, some militant Muslim groups, and particularly the Islamic State, have created ever-widening space for attacking those traditionally considered immune from targeting in military operations. Our essay uses two theoretical apparatuses developed in social psychology-cultural cognition and moral foundations theory-to explain how certain aspects of post-9/11 tactics on the part of the United States and its allies have contributed to this phenomenon. We also use these same tools to show that similar dynamics work to contribute to the rightwing backlash against Muslims in the United States.
\end{abstract}

Keywords: military ethics; Muslim ethics; just war theory; noncombatant immunity; discrimination; cultural cognition; moral foundation theory

\section{Background}

If the Islamic State (ISIS) group is known for one thing among the general public in the West, it is its brutality. It is not difficult to recall-indeed, it is difficult to forget—-the images of Islamic State fighters killing prisoners, Western journalists, and even aid workers in gruesome fashion on international television. These images were most prevalent between 2014 and 2016 when, in addition to committing large numbers of executions, ISIS was taking control of significant chunks of land in Syria and Iraq and inspiring numerous terror attacks in the West. The level of coverage has shrunk with the size of its geographical holdings, but ISIS continues to inspire and encourage attacks against civilian populations and they continue to justify these attacks by appealing to traditional Islamic sources. While Islamic tradition has a long history of prohibiting the targeting of noncombatants, various militant groups have found ways of getting around the prohibition while still holding to the prima facie distinction between combatants and noncombatants, usually by appealing to certain exceptional circumstances that temporarily require such targeting. That is to say, the prohibition is overridden, but only in particular, drastic situations. ISIS, however, is different. Not only do they target noncombatants, they do so with a sense of great enthusiasm and as part of what they see as a state of affairs that will endure until the black flag governs the entire world. And they use this brutality as a tool for their propaganda. In their eyes, their legitimacy is not threatened, but is strengthened, by the level of brutality they are able to inflict on noncombatants. How, then, despite the prohibition against targeting noncombatants in Muslim tradition, did ISIS come to the place of not only ordering, but sensationalizing the brutal, targeted killing of civilians?

There is longstanding tension in Islamic jurisprudence between taqlid, following the judgments of an established scholar, and ijtihad, arriving at a Shari a ruling on one's own. Traditionally, ijtihad was only performed by scholars who had gone through a long, formal process of study at the feet of recognized authorities. In recent decades, however, a certain democratization has occurred, such 
that some without formal legal training have begun to issue legal rulings, and some have found substantial followings in doing so. One helpful way of approaching these tensions while accounting for both continuity and change in the tradition is provided by John Kelsay, who argues that Muslim ethical discourse tends to function according to the more or less formal procedures and norms of what he calls Shari a reasoning. This framework includes methods of interpreting and applying the Qur' an and sunna (precedent-setting traditions about the life and sayings of Muhammad) as well as specific judgments reached by scholars of previous times. Shari a reasoning also involves achieving a balance between respect for the past and creativity regarding application in the present. Kelsay thus suggests that Muslims tend to treat Islamic tradition as a body of precedents that must be respected; but practitioners must also seek to find the right fit between the precedent and a particular situation. It is not surprising, therefore, that while the broad norms of Shari'a reasoning are relatively stable, their application includes a good deal of diversity and disagreement (Kelsay 2007, p. 73).

This essay uses the framework of Shari'a reasoning to understand how the Islamic State group has approached the issue of targeting noncombatants. However, whereas Kelsay tends to focus on the ways that ethical reasoning functions in light of precedents in Islamic tradition, we emphasize the ways that a sense of fit guides the use of precedents. More specifically, we argue that the Islamic State's arguments justifying the targeting of noncombatants stretch the use of precedents beyond the norms of Islamic tradition, such that to understand ISIS on this point one must understand the factors that contribute to their sense of "fit". While a comprehensive case would require much more than one essay, we suggest that two psychological paradigms, moral foundations theory and cultural cognition, can help to shed light on the deepening extremism of ISIS beyond their predecessors. In emphasizing the importance of cultural conflict in the formation of ethical norms, both of these paradigms also point to the significance of anti-Muslim rhetoric and actions on the part of important officials in the United States in fueling anti-Western extremism in general and the targeting of noncombatants in particular among militant Muslims. At the same time, we suggest, similar cultural dynamics in the West have fueled a political climate in which continued forms of Islamophobia have contributed to the relaxation of the prohibition against targeting noncombatants on the part of the United States.

\section{Case Study: Targeting Noncombatants in Muslim Tradition and the Islamic State}

Much of the classical Muslim tradition concerning noncombatant immunity can be summarized in a tradition of Muhammad, in which he charges his army when they go out to fight, "Do not cheat or commit treachery, nor should you mutilate anyone or kill children," a prohibition that in other traditions also includes protections for women and aged men (al-Shaybani 1966, pp. 76, 92). These prohibitions, when combined with other practices in Muhammad's life, form the basis of a longstanding Muslim tradition that has sometimes been expanded to include prohibiting the targeting of slaves and the elderly [see (al-Shaybani 1966, p. 76) as well as (Kelsay 2007, p. 114)]. However, as in Western traditions, it has been generally recognized among Muslims that some noncombatants may be killed unintentionally in the process of a legitimate attack.

In recent decades, Muslims have nearly always accepted a prima facie commitment to noncombatant immunity. Disagreements continue, however, most notably concerning which persons count as noncombatants. Some have argued that war in Islam should only be defensive in nature and that the command protecting noncombatants from targeted attacks is inviolable. For example, in their "Open Letter to Baghdadi (2014)", a rebuke of the Islamic State, a large international group of leading Muslim scholars and jurists argue in favor of a very firm prohibition against targeting noncombatants, such that "only combatants may be killed; their families and noncombatants may not be killed intentionally" (sec. 8.d). Others, such as Yusuf al-Qaradawi, have argued for the temporary suspension of the prohibition in order to address a kind of emergency situation. But when that emergency passed, Qaradawi reversed his opinion (Lieber 2017).

So significant is the prohibition against targeting noncombatants that even jihadi militants such as Osama bin Laden tend to observe its prima facie status. He overcomes the prohibition by expanding 
greatly those who count as combatants. Citizens of the United States, bin Laden argued in 2002, are responsible for their leaders because they live in a democracy. That is to say, the United States cannot claim to have any true noncombatants: all are responsible for the crimes of the national government (bin Laden 2005, p. 164).

As important for bin Laden, however, is a kind of principle of reciprocity, which he suggests overrides the command to distinguish between soldiers and civilians. In a famous interview with Taysir Aluni in October of 2001, bin Laden made the following argument about the permissibility of targeting noncombatants:

The Prophet forbade the killing of children and women, and that is true. It is valid and has been laid down by the Prophet in an authentic Tradition .... but this forbidding of killing children and innocents is not set in stone, and there are other writings that uphold it. God's saying: "and if you punish (your enemy, O you believers in the Oneness of God), then punish them with the like of that which you were afflicted ... " The scholars and people of the knowledge, amongst them Sahib al-Ikhtiyarat [ibn Taymiyya] and ibn al-Qayyim, and Shawaani, and many others, and Qurtubi-may God bless him—in his Qur'an commentary, say that if the disbelievers were to kill our children and women, then we should not feel ashamed to do the same to them, mainly to deter them from trying to kill our children and women again. (2005, pp. 118-19)

Bin Laden, then, although his arguments show signs of internal inconsistency, takes pains to justify targeting those usually considered noncombatants. Notice, as well, that the reciprocity that bin Laden cites includes a particular intention-preventing one's enemies from continuing to kill noncombatants on one's side.

The Islamic State group is considerably less invested in any form of prima facie noncombatant immunity than is bin Laden. We might say that while bin Laden sees the targeting of noncombatants as an unfortunate but just temporary necessity given the wicked deeds of his enemies, the Islamic State eagerly encourages the targeting of those uninvolved in any war effort, and not so much because of their deeds as because of their status as unbelievers. This is perhaps most clearly stated in an article in the first issue of their magazine Rumiyah, "The Kafir's Blood is Halal for You, So Shed It". The style of argumentation is common to many of their official publications, offering vivid imagery, vicious rhetoric, and the sternest interpretations buttressed by citations to the Qur'an, hadith, and many classical sources-although invariably without context. The first part of the argument is somewhat familiar among Islamic militants, with references to the sword verse ${ }^{1}$ and an interpretation suggesting that Muslims are duty-bound to fight non-Muslims who are not granted dhimmi status. The Islamic State takes things considerably further, however, in both its tone and argument. The tone can be summarized in the brutal declaration that "the blood of a kafir is cheap, filthy, and permissible to shed" (35). The argument involves erasing the distinction between combatants and noncombatants while declaring it a religious duty to extend the battle lines to any place where disbelievers may be found. Instead of a prima facie prohibition against killing noncombatants, the Islamic State declares a prima facie order to kill disbelievers unless they fall under the terms of a specific covenant of protection.

Muslims currently living in Dar al-Kufr [the territory of unbelief] must be reminded that the blood of the disbelievers is halal [permissible], and killing them is a form of worship to Allah, the Lord, King, and God of mankind. This includes the businessman riding to work in a taxicab, the young adults (post-pubescent "children") engaged in sports activities in the park, and the old man waiting in line to buy a sandwich. Indeed, even the blood of the kafir street vendor selling flowers to those passing by is halal to shed-and striking terror into the hearts of all disbelievers is a Muslim's duty. There is no shar'i requirement to target 
soldiers and policemen nor judges and politicians, but all kuffar [unbelievers] who are not under the covenant of dhimmah are fair game. How can the disbelievers ever dream of safety and security while Muslims suffer anywhere in the world and while the rule of Allah is mockingly replaced by manmade monstrosities of democracy? (36)

For the Islamic State, then, the distinction between combatants and noncombatant is largely insignificant. The only category that matters is one's status as a Muslim. The rhetorical strategy of the Rumiyah piece seeks to incite violence by Muslims against those in the West, so no distinctions between Muslims are mentioned. It is clear elsewhere, however, that a person's status as a Muslim is determined by her loyalty to the Islamic State, such that the overwhelming majority of the world's population are considered disbelievers (and legitimate targets), including the Shi 'a and most Sunnis (al-Ibrahim 2015).

\section{Analysis: Identity, Cultural Conflict, and Justification for Targeting Noncombatants}

Why is ISIS pushing beyond the boundaries of the precedents of traditional Shari'a reasoning to blur, even erase, the distinction between combatants and noncombatants? One answer might involve investigating the group's selective and sometimes faulty interpretations of classical sources. Such work is important and can be very helpful in illustrating the ways in which ISIS departs from mainstream, and even other forms of militant, Islam. The multidimensional and multidisciplinary fields that comprise cognitive science, however, suggest that judgments, including ethical judgments, are not generally the result of a simple process of self-aware, rational deliberation. Instead, even considered judgments are the outcome of a mixture of intuitions, emotions, and deliberations, all of which are experienced and worked out through a messy process involving culturally constructed norms and, often, interpersonal communication. ${ }^{2}$ To understand why ISIS takes this position concerning noncombatants, then, one must offer an explanation that goes beyond their interpretation of texts. One must explain how they derive their sense of "fit".

A helpful tool for beginning to explain why ISIS's approach differs from that of al-Qaeda and other militant groups is moral foundations theory (MFT), a conceptual scheme developed by Jonathan Haidt and others to explain the aspects of both continuity and uniqueness between human moral systems. One aspect of continuity that Haidt identifies is the process of moral decision making and deliberation, a process he describes as "social intuitionist" in nature. The process is "intuitionist" insofar as moral intuitions come first, both temporally and in terms of priority, with rational deliberation coming second. It is "social" because morality is viewed as a strategy for influencing other people rather than an aspect of an individual's search for personal meaning. Continuity in human morality is also found in its substance and is derived, according to Haidt, by five or six foundations that are rooted in human evolutionary biology: liberty vs. oppression; care vs. harm; fairness vs. cheating; ingroup loyalty vs. betrayal; authority vs. subversion; and sanctity vs. degradation. The theory leaves a good deal of fluidity in how these foundations are actualized in historical communities and individuals, however, since each foundation is emphasized and interpreted differently according to a wide variety of historical settings and cultural norms by people with their own idiosyncrasies.

If moral intuitions come first and deliberation second, as moral foundations theory indicates, then we can begin to see how a sense of fit influences the choice and interpretation of precedents. But MFT is helpful in another sense, too, in that Haidt draws a distinction between "individualizing" foundations (liberty vs. oppression, care vs. harm, and fairness vs. cheating) that highlight the importance of individual human beings and "binding" foundations (ingroup loyalty vs. betrayal, authority vs. subversion, and sanctity vs. degradation) that emphasize the values that undergird group solidarity. In the American context, Haidt suggests, liberals tend to focus only on the individualizing foundations, and particularly on liberty and care, whereas conservatives are traditionally more prone

2 See, for example, (Kahneman 2011; Haidt 2012; Greene 2013; Sapolsky 2017). 
to put all of the foundations on roughly equal footing. ${ }^{3}$ When we move to think about groups that embody rightwing authoritarianism, such as al-Qaeda and especially ISIS, we find that the binding foundations take on a remarkable emphasis to the point that commitments to care and liberty (individualizing foundations) become relativized under the aegis of loyalty, authority, and sanctity (the binding foundations).

More specifically, al-Qaeda and ISIS both weld authority and loyalty together to form a lens through which the other foundations are interpreted. These central foundations are not understood in precisely the same fashion, however. Bin Laden's instinct was to work to unite ordinary Sunnis by emphasizing the oppression of the West. In conjunction with that instinct, while bin Laden did not hesitate to declare certain regimes apostate, he was much slower to make such declarations against common Muslims, especially Sunnis. For ISIS, however, the circle of loyalty is drawn much tighter and is explicitly linked to one's loyalty to the Islamic State. The authority foundation is conceived in a tighter fashion as well. Although bin Laden was often strident in his religious interpretations and dismissive of others, there was generally a sense that he understood something of a distinction, at least in principal, between his interpretations and the sources of authority, the Qur' an and the hadith. This distinction is blurred with the Islamic State. On one hand, they acknowledge that their legitimacy depends upon fulfilling the Shari a requirements for leadership. On the other hand, because those requirements have been met (according to them), their interpretations are seen as binding on all Muslims. In this way, authority is tied to a concrete political entity, binding authority and loyalty together in a way that was not possible for bin Laden. Those loyal to the authority of the Islamic State receive considerations of care, liberty, and fairness as deemed appropriate by the State. Others receive no such consideration at all.

While MFT works to explain how intuitions might work to shape a person's basic moral approach, it doesn't tell us much specifically about how a sense of fit relates to the interpretation and adjudication of precedents. It is essential to note, therefore, that an important aspect of group belonging is developed through narrative, in which an individual takes up a position within a story told by the group. Group identification can become very intense when a process dubbed by social psychologists as "identity fusion" occurs. Essentially, the individual's identity becomes one with the group in a robust, visceral sense, such that the individual reacts—cognitively and emotionally—to the experiences of others in the group as though they were one's own, as evinced by bin Laden's application of reciprocity and the Islamic State's to the worldwide suffering of Muslims.

In this regard, another theoretical apparatus called cultural cognition becomes very helpful. Cultural cognition, a term developed by a multidisciplinary research team housed at Yale Law School, refers to the way that individuals tend to adopt views that fit with their cultural identities when facing disputed matters. When deciding whether they believe that human beings are causing global warming or whether gun control prevents gun violence-or, we argue, whether noncombatants can be justifiably targeted in military operations-people don't characteristically base their views on the best available evidence (whatever they tell themselves), but upon a sense of how they ought to respond as part of a cultural group.

There are three main processes that comprise cultural cognition: motivated reasoning, identity protective cognition, and naïve realism. Motivated reasoning "refers to the unconscious tendency of individuals to process information in a manner that suits some end or goal extrinsic to the formation of accurate beliefs" (Kahan 2011). The idea, supported by scores of experiments as well as other data (cognitive science, polls, ethnographic accounts, political analyses, and so forth), is that people characteristically, but unwittingly, manipulate data in service to a particular goal other than that of arriving at a valid or true conclusion. Evidence is weighted in a certain fashion, sensory perceptions

3 We say "traditionally" because Haidt's major work on the subject was published in 2011, before the rise of Donald Trump. For brief comments by Haidt on Trump, see (Edsall 2016). 
are interpreted in such a way, and/or reasoning processes are manipulated in order to legitimize a particular conclusion or point of view, often in an unconscious effort to regulate one's emotions (Westen et al. 2006). However, throughout all of this, the one doing the reasoning honestly believes she is expending mental energy only in service of the truth.

In the case of the Islamic State, motivated reasoning is perhaps most apparent in the ways that they selectively interpret the tradition, and their selectivity is perhaps most apparent in their interpretation of the so-called "sword verse", Qur' an 9:5, which is rendered in the "Kafir's Blood" article as "So when the sacred months have passed, then kill the mushrikin wherever you find them and take them, surround them, and wait for them at every outpost." As noted above, the Islamic State takes this verse to mean that Muslims are always and everywhere to target disbelieving noncombatants for killing. This interpretation is selective in at least two senses. First, it ignores the textual context of the verse's revelation, disregarding the surrounding verses. More than that, it cuts out the second half of the verse, which reads: "But if they should repent, establish prayer, and give zakah, let them [go] on their way. Indeed, Allah is Forgiving and Merciful". ${ }^{4}$ Second, historically speaking, the verse referred to polytheists of the Arabian Peninsula, not to Jews and Christians or other "People of the Book" ${ }^{5}$ We are suggesting, therefore, that these kinds of interpretive shortcuts are one piece of evidence that the reasoning of Islamic State ideologues is motivated not by a desire to understand the text in all of its complexity, but to justify the established practices of the group.

The goals to which motivated reasoning applies are legion, but, as with ISIS, by far the most researched aims are political and moral in nature. Some such goals are related to the interests or values of the individual, such as rationalizing or forgetting one's dishonesty. Those that are most relevant to the current discussion, however, have to do with the way that motivated reasoning functions in relation to one's group identity. The classic study of this kind, "They Saw a Game", was published by Albert H. Hastorf and Hadley Cantril in 1954 (Hastorf and Cantril 1954) and was based upon a particularly rough football game between Princeton and Dartmouth. Students who attended the game were asked to give their general impressions of the conduct of each team. Other students, who did not attend, were shown film of the game and, in addition to giving their general impressions after watching the film, were asked to imagine themselves as referees of the game, citing infractions as they watched. In a process that is intimately familiar around the world, students from both universities consistently biased their reports in favor of their team. Princeton students overwhelmingly thought the Dartmouth team was playing dirty by purposely injuring their star player, whereas Dartmouth students held that the player was injured accidentally and that the Princeton team was bent on revenge for the rest of the game. The major finding of the experiment, and that which most interests cultural cognition researchers, is that students from Princeton saw a qualitatively different game from that of the Dartmouth students, yet students from both schools assumed (and believed) that their interpretation of the game was objectively accurate. These phenomena are referred to as identity-protective cognition and naïve realism.

Identity-protective cognition involves a number of processes that are implicitly mobilized in order to protect one's identity within a particular group, often blurring the line between the self and the group such that the individual is personally threatened by opposition to the group's values or interests. In essence, one takes up the group's values and identity as one's own via identity fusion, and this motivates the individual's reasoning. Identity-protective cognition tends to make relations between groups difficult because each side characteristically interprets contested matters in a self-serving way. In the case of ISIS, identity-protective cognition plays a particularly important role insofar as loyalty to the group and its authority form the core of their ethical position.

4 Sahih International version.

5 For more examples of how ISIS selectively interprets scripture, see (Siddiqui 2015). For more discussion on the contest of Qur'an 9:5, see (Esposito 2015). 
Just as important is the phenomenon of naïve realism, an "asymmetry in the ability of individuals to perceive the impact of identity-protective cognition" (Kahan 2011, p. 22). Essentially, members of a group tend to be quite adept at noticing the biases of other groups (realism), but much less skilled in acknowledging their own (naivety). This asymmetry introduces a situation in which the questioning of one's (or one's group's) position or interests is often seen as a biased or even bad-faith attack, ushering in resentments that, in some cases, shift the argument away from the issues at hand in favor of attacks on the integrity of one's opponents. If matters take this kind of turn, a vicious circle is often started in which each group continually, but unknowingly, reenacts the naïve realism at the heart of the original conflict.

ISIS, again, exhibits these patterns in a number of ways. Like many critics of the West, Islamic State ideologues are skilled at pointing out real ethical failures on the part of the West, particularly concerning policies that are harmful to Muslims or Muslim-majority countries. A strong degree of naivety is evident, however, insofar as the group is unable or unwilling to offer any measure of self-criticism, or even self-awareness. So too, they routinely attack the integrity of their opponents. One common strategy is to offer summary judgments that strain credulity, such as when in the "Kafir's Blood" article they suggest that "any Muslim who has studied his religion" will understand that scholars have reached a consensus that noncombatant disbelievers should be targeted (36). At other times, they argue that their opponents have lost the ability to recognize even the most self-evidentiary truths because they have given in to corruption to the point of losing their God-given human nature, or fitra. ${ }^{6}$

What we see with ISIS and in other situations rife with group conflict, moreover, is that cultural cognition is at the center of a larger set of processes that harden the boundaries between "Us" and "Them". In certain extreme instances, these boundaries can become so rigid that those considered other, "Them", are dehumanized to the point that they no longer deserve the kind of treatment normally accorded to fellow human beings. When cultural cognition is rooted in an intense privileging of the binding foundations (loyalty, authority, and sanctity), one can see how easily the jump to dehumanization can be made (Waller 2002, pp. 236-57).

More broadly, moral foundations theory and cultural cognition both suggest that ethical reasoning is in large measure an explicit working out of one's moral intuitions which, in many cases, is rooted in one's sense of group belonging. Intuitions and deeply felt convictions tend to come first: reasoning, which is influenced by a broad number of social dynamics and cognitive biases, comes second. Insofar as the Islamic State is concerned, therefore, we suggest that Shari 'a reasoning is not employed as a means of reaching the conclusion that noncombatants should be targeted. Rather, Shari a reasoning is selectively employed as a means of justifying the deeply held conviction that there is no distinction between enemies of the Islamic State: all are under God's judgment and worthy of execution.

\section{Conclusions: Cultural Conflict in Circular Perspective}

Of course, none of these processes function in a vacuum: they are employed, however unconsciously, in the light of real-world conflicts as defense against real-world opponents, or enemies. And they are not the sole provenance of Muslim militants but are employed by most of us in one form or another, depending both on the particulars of the cultural conflict in question and the structures of our moral intuitions. In the rest of this essay, we point briefly to some of the concrete ways that historical events and interpretations might engage the process of cultural cognition and push people toward adopting the various aspects of rightwing authoritarianism.

It is not difficult to see, for example, how these patterns and mechanisms might lead certain people to adopt a general attitude of opposition to the West. As a general typology, the thinking may function roughly as follows. Many Muslims are acutely aware of the suffering experienced by their

6 See especially "The Fitrah of Mankind and the Near Extinction of the Western Woman" in Dabiq, issue 15 (20-25). 
fellow Muslims throughout much of the globe, a suffering that is experienced on some level as one's own, in large measure because of a shared religious identity. The consciousness of this suffering is paired with a broadly, although not universally, accepted narrative that juxtaposes the greatness of premodern Islamic civilization with the poverty, tyranny, and indignities that Muslims have endured under colonialism and the continued meddling of the West in Palestine, Iran, Iraq, India, Egypt, and elsewhere. Sometimes this narrative is framed in grand language of civilizational struggle in which Israel, Europe, and the United States are depicted as extensions of the crusades or the state of willful ignorance exemplified by pre-Islamic Arabia. Other times the language is more localized, emphasizing the specific blame due to a particular group of people. But whatever the case, this suffering and these narratives work to activate the processes of cultural cognition, such that, for some, reasoning about these matters becomes more an exercise in justifying one's beliefs by marshalling evidence against the West than an attempt to come to an accurate assessment of the situation by means of Shari' a reasoning.

Moreover, recent events and policies on the part of the West, and particularly the United States, might exasperate matters and push certain Muslims to subsume the individualizing foundations within the binding foundations. Implicit and explicit Islamophobia, for example, frames public discourse in such a way that Muslim identity is emphasized at the expense of other possible identifications (racial, ethnic, class, and so on). Those who suffer the pain of discrimination under the rubric of Islamophobia do so as Muslims, such that their moral reactions are very likely to stem from the binding foundations, particularly as violations against the loyalty they feel toward their group and the sanctity of the group's most deeply held beliefs.

Or consider the war on terror. While explicitly waged against an abstraction, "terror", targets of the war on terror are almost exclusively Muslims. Morally questionable tactics that target Muslims such as torture, rendition, certain forms of drone strikes, the treatment of prisoners at Abu Ghraib, and many other instances are very likely to trigger strong reactions rooted in the loyalty and sanctity foundations. And inhumane actions on the part of one's enemies, however real or perceived, make the path toward dehumanizing those enemies all the easier.

It would be wrong to think, however, that these kinds of dynamics are limited to Muslims, or to Muslim militants. They are, rather, very widespread, and particularly so in the context of cultural conflict. Let us return to the example of targeting noncombatants in the West. As in the Muslim tradition, the just war tradition and international law both prohibit the targeting of noncombatants. Commitment to these norms has been tested in recent years, however, in the context of the war on terror, where both George W. Bush and Barack Obama authorized the use of "signature" drone strikes, a practice that allows American drones to strike vehicle convoys without verifying the identities of potential targets so long as they possess certain, rather slippery, signature attributes such as age, actions, and location (Himes 2016). Yet, Bush and Obama were both careful to maintain the prima facie prohibition against targeting noncombatants, each arguing in their own ways that signature strikes satisfied the prohibition. Donald Trump's approach is another matter. He has largely delegated drone policies to his military commanders. His rhetoric, however, suggests a remarkably cavalier attitude toward concerns related to the principle of discrimination. For example, on 2 December 2015, then-candidate Trump said on Fox News:

We're fighting a very politically correct war. And the other thing is with the terrorists, you have to take out their families. When you get these terrorists, you have to take out their families. They, they care about their lives, don't kid yourselves. But they say they don't care about their lives. You have to take out their families. (Fox and Friends 2015)

Although he later publicly reversed position on targeting the families of terrorists, these sentiments were reportedly repeated on his first day in office during a visit to CIA headquarters (Jaffe 2018).

More than that, Trump's attitude toward targeting noncombatants is part of a broader, fiery, rhetorical disposition through which Trump appeals to his base by drawing hard boundaries between "Us" and "Them", with Muslims often cast in the role of "Them". For example, shortly after the Islamic 
State-inspired Barcelona terror attack in August of 2017, then-candidate Trump addressed the question of how best to deal with terrorism by referencing a spurious story about American General John J. Pershing's tactics for snuffing out insurgency in the Philippines in the early 20th century. As Trump explained it:

General Pershing was a rough guy. And he sits on his horse, very astute like a ramdrod. Right? And, the year was early nineteen hundreds. And this was a terrible problem. They were having terrorism problems just like we do. And he caught 50 terrorists who did tremendous damage and killed many people. And he took the 50 terrorists, and he took fifty men, and he dipped 50 bullets in pigs' blood. You heard that, right? He fit, he took 50 bullets, and he dipped them in pigs' blood. And he had his men load his rifles. And he lined up the 50 people. And they shot 49 of those people. And the 50th person, he said "you go back to your people and you tell them what happened". And for 25 years there wasn't a problem. (Reilly 2017)

The reader will notice the similarities between Trump's approach and that of the Islamic State: appeals to brutality against the Other, appeals which include a strong element of dehumanization, work to trigger the values associated with the binding foundations of loyalty, authority, and sanctity. Moreover, commitment to the individualizing foundations is subsumed under the binding foundations, such that the normal treatment generally according to other human beings-such as prohibitions against execution of prisoners or targeting noncombatants—can be suspended in light of the priority given to protecting the group.

Perhaps most troubling, Trump's statements have gained some traction among the public. As with ISIS, this support seems to be grounded, at least to some degree, in a kind of reaction to the brutality of one's opponents. Just as the Islamic State's appeal is specific to a historical context that includes signature drone strikes, the treatment of prisoners at Abu Ghraib, and other questionable tactics in the war on terror, so Trump's appeal is contextualized by the brutality of groups like al-Qaeda and ISIS, and especially by the $9 / 11$ attacks. That is to say, the disconcerting prioritization of the binding foundations and their justification through cultural cognition by those inclined toward rightwing authoritarianism may not be empirically or ethically justifiable, but they are not conjured from nothing. They are, in large measure, reactions against unjust behavior.

If this analysis is correct, it suggests that regaining a strong commitment to the prohibition against targeting noncombatants will be a difficult task. Yes, ISIS may be defeated on the battlefield and Trump and his ilk may be removed from office. Both of these developments may lead to policies more in keeping with the traditional commitment to the principle of discrimination. By our way of thinking, however, such policy changes would alleviate a symptom of an underlying problem. The heart of the matter, we are suggesting, has to do with the perception among some that there is a cultural struggle between the West and Islam. If this problematic perception is to be undone, it will take a sea change in political rhetoric, domestic and foreign policy, military tactics, and education by a number of governments and other institutions over an extended period of time. Only time will tell whether we have the resolve to make these changes.

Author Contributions: Conceptualization, R.M. and S.B.; Methodology, R.M.; Writing-Original Draft Preparation, R.M. and S.B.; Writing-Review \& Editing, R.M. and S.B.

Funding: This research received no external funding.

Acknowledgments: The authors would like to thank Sohail Hashmi for editing this special issue and for inviting us to contribute.

Conflicts of Interest: The authors declare no conflict of interest. 


\section{References}

al-Ibrahim, Bader. 2015. ISIS, Wahhabism, and Takfir. Contemporary Arab Affairs 8: 408-15. [CrossRef]

al-Shaybani, Muhammad. 1966. The Islamic Law of Nations: Shaybānī's Siyar. Translated by Majid Khadduri. Baltimore: The Johns Hopkins Press.

bin Laden, Osama. 2005. Messages to the World: The Statements of Osama Bin Laden. Edited by Bruce Lawrence. Translated by James Howarth. Brooklyn: Verso.

Edsall, Thomas B. 2016. Purity, Disgust and Donald Trump. The New York Times. January 6. Available online: https:/ /www.nytimes.com/2016/01/06/opinion/campaign-stops/purity-disgust-and-donaldtrump.html (accessed on 20 June 2018).

Esposito, John. 2015. Islam and Political Violence. Religions 6: 1067-81. [CrossRef]

Greene, Joshua. 2013. Moral Tribes: Emotion, Reason, and the Gap between Us and Them. New York: Penguin Press.

Haidt, Jonathan. 2012. The Righteous Mind: Why Good People Are Divided by Politics and Religion. New York: Pantheon Books.

Hastorf, Albert H., and Hadley Cantril. 1954. They saw a game; a case study. Journal of Abnormal Psychology 49: 129-34. [CrossRef] [PubMed]

Himes, Kenneth. 2016. Drones and the Ethics of Targeted Killing. London: Rowman \& Littlefield.

Jaffe, Greg. 2018. For Trump and his generals, 'victory' has very different meanings. The Washington Post. April 5. Available online: https://www.washingtonpost.com/world/national-security/for-trump-andhis-generals-victory-has-different-meanings/2018/04/05/8d74eab0-381d-11e8-9c0a-85d477d9a226_story. html?noredirect=on\&utm_term=.7a18cf413e98 (accessed on 10 June 2018).

Kahan, Dan M. 2011. Neutral Principles, Motivated Cognition, and Some Problems for Constitutional Law. Harvard Law Review 125: 1-78.

Kahneman, Daniel. 2011. Thinking, Fast and Slow. New York: Farrar Strauss and Giroux.

Kelsay, John. 2007. Arguing the Just War in Islam. Cambridge: Harvard University Press.

Lieber, Dov. 2017. The cleric who legitimized suicide attacks against Israel has reversed his ruling. Hamas isn't listening. The Times of Israel. January 10. Available online: http:/ / www.timesofisrael.com/the-clericwho-legitimized-suicide-attacks-against-israel-has-reversed-his-ruling-hamas-isnt-listening/ (accessed on 6 April 2018).

2014. Open Letter to Dr. Ibrahim Awwad al-Badri, Alias 'Abu Bakr al-Baghdadi', and to the Fighters and Followers of the Self-Declared 'Islamic State'. Available online: http:/ /www.lettertobaghdadi.com/ (accessed on 2 April 2018).

Reilly, Katie. 2017. President Trump Praises Fake Story about Shooting Muslims with Pig's Blood-Soaked Bullets. Time Magazine. August 17. Available online: http:/ / time.com/4905420/donald-trump-pershing-pigs-bloodmuslim-tweet/ (accessed on 25 July 2018).

Sapolsky, Robert M. 2017. Behave: The Biology of Humans at Our Best and Worst. New York: Penguin.

Siddiqui, Sohaira. 2015. Beyond Authenticity: ISIS and the Islamic Legal Tradition. Jadaliyya. February 24. Available online: http:/ / www.jadaliyya.com/Details/31825/Beyond-Authenticity-ISIS-and-the-IslamicLegal-Tradition (accessed on 25 July 2018).

Waller, James. 2002. Becoming Evil: How Ordinary Peope Commit Genocide and Mass Killing. Oxford: Oxford University Press.

Westen, Drew, Pavel S. Blagov, Keith Harenski, Clint Kilts, and Stephan Hamann. 2006. Neural Bases of Motivated Reasoning: An fMRI Study of Emotional Constraints on Partisan Political Judgment in the 2004 U.S. Presidential Election. Journal of Cognitive Neuroscience 18: 1947-58. [CrossRef] [PubMed]

(C) 2018 by the authors. Licensee MDPI, Basel, Switzerland. This article is an open access article distributed under the terms and conditions of the Creative Commons Attribution (CC BY) license (http:/ / creativecommons.org/licenses/by/4.0/). 